\title{
The lake, the birds, and the people
}

\author{
Rahmawaty Kadir ${ }^{1}$ \\ ${ }^{1}$ Department of Secondary Education, University of Alberta, Edmonton, Canada \\ E-mail: Rahmawat@ualberta.ca
}

I saw my nene in my dream last night.

She was beautiful with her kerudung.

She said to me, "Nou, donggo motota yio mohulondalo?"

I said "motota watiya nene, openu bo ngoputu ngoputu."

She smiled.

She left, leaving me awake for the rest of the night.

I talk in my silence.

O you, the daughter of Holondalangi. Have you found your dream yet?

Your tongue must have been numb. Does it still dance as it should be?

"Moalato." It said to me.

Dan akupun terdiam.

I hear the mother, Limboto lake, calling my name from faraway.

"No'u, pohuwalingo pomayi. I am drying, dirty, and dying."

The lake cries as her water dries up.

Leaving her alone with mud and stone.

I paused.

I sob.

I hear the Bondula sings a sad ballad. The saddest one I have ever heard.

They have been hunted, trapped, and killed.

"Alas, tingga pongolomu” kata mereka.

The wind blows their melody to this majestic land tackling the same fate.

I grieved.

Gathering my sense, I walked my mind passing the time.

I heard a little boy counting "satu, dua, tiga."

His grandma asked him, "what language is it?"

He said, "it is the language on TV, a language that unifies us."

Grandma weeps and walks away.

Enough I told. But, It is not the end yet.
My nene is there, singing Lohidu lo Hulondalo.

"Strangers in our door," she began.

Asked us to repeat our words.

We said them once, twice, thrice. But they asked for more and more.

Till our tongue got bitter and sore. No more.

The Bone River flows in your vein, but you just watch us from faraway.

Pain. Mongoto.

The canting is still there, wunugo lo Hulondalo.

Calling the name of Bulalo lo limutu, Bandula lo limutu,

Holondalo nga'a mila.

But still the lake cries its water,

the bird sings its song,

and the language calls its people.

This poem describes the author's experiences as a speaker of Gorontalo, one of Indonesia's Indigenous languages. This language is listed as a threatened language in Indonesia by the Ethnologue (Eberhard et al. 2021) and the Indonesian Ministry of Education and Culture (2020). In this poem, she uses Gorontalo, Indonesian, and English to raise awareness of biodiversity and language endangerment in her community and the world.

\section{Works cited}

Eberhard, David, et al. Ethnologue: Languages of the World. 24th ed., SIL International, 2021.

The Indonesian Ministry of Education and Culture. Gambaran Kondisi Vitalitas Bahasa Daerah di Indonesia Berdasarkan Data Tahun 2018 - 2019. Ebook, Kemendikbud, 2000. 